\title{
Assessment of Low Cost Technologies for Drudgery Mitigation in Ginger Production System
}

\author{
Jayshree Rodge*, Manjusha Rewanwar and Swati Gaikwad
}

AICRP (FRM Component), College of Home Science, VNMKV, Parbhani, India

*Corresponding author

\section{A B S T R A C T}

\section{Keywords}

Improved method, Existing method, Ginger production

\section{Article Info}

Accepted:

28 July 2020

Available Online:

10 August 2020
Low cost technologies developed for turmeric production system were tested in ginger production system. Physiological workload of the selected women workers while performing selected activities in ginger production system was assessed by heart rate method. Total 46 healthy farm workers working in the field for 6-7 hrs/ day were selected for the study. Study was conducted in Pokharni, Katneshwar, Nandgaon, Bharati Camp Dist. Parbhani \& Hatta, Adgaon, Satephal villages of Dist. Hingoli. For collection of data 46 female workers, three replications, 5 activities viz. planting, weeding, earthing up, fertilizer application, Harvesting, Sorting \& cleaning and two methods i. e. existing and improved were selected. It was seen that Cardiac cost of work for planting and earthing up activities performed by women farm worker in improved method over existing method was reduced by 16 and 12 percent respectively in Ginger production system. Rated perceived exertion was decreased by 13-32 per cent in improved method of planting, weeding, earthing up and manual fertilizer application and harvesting and cleaning activities. The developed technologies viz. digging tools (Ukari and finger guards), new khurpi, Sulbha bag and Earthing up tool (Sawadi) used by farm women in ginger production system for planting, weeding, earthing up and manual fertilizer application activities were successful in increasing pace of work.

\section{Introduction}

Ginger is very important commercial crop grown for its aromatic rhizomes which are used both spice and medicine. Ginger (Zingiber officinale Rosc.) (Family: Zingiberaceae) is an herbaceous perennial, the rhizomes of which are used as a spice. India is a leading producer of ginger in the world. Ginger is cultivated on area of $1,05,500$ hectares with production of 5.17 lakh tonnes in India (2). It is marketed in different forms such as row ginger, dry ginger, bleached dry ginger, ginger powder, ginger oil, ginger ale, ginger candy, ginger beer, ginger wine, ginger squash, ginger flex etc. It is propagated through rhizomes. The rhizomes put forth erect, leafy stems, $30-90 \mathrm{~cm}$ in height. The base of the leaves sheathe the stem. The leaves are dark green, $15-20 \mathrm{~cm}$ long, narrow, lanceolate and with prominent midrib. The flowers are small, yellowish, spackled, each with a purple speckled lip and borne on spike. When the plants are about 9 months old, the 
green leaves turn yellow. Ginger produced in India goes for domestic consumption and only a small quantity is exported (IndiaAgronet.com).

Planting is performed with light digging. About 6 to 8 inches depth small block is made by hand for planting rhizomes. Majority of women make the small hole on ridges with the help of hand. Farmers were not using any tool or implement for earthing up activity, they perform this activity by hands. After performing earthing up activity continuously for $6 \mathrm{hrs}$., major health problems of the farm women reported were burning sensation to the skin, skin coming out and skin allergy. Hence, seven tools developed for turmeric production system by AICRP (FRM Component) College of Home Science were tested for it's effectiveness in ginger production system.

\section{Materials and Methods}

Package of seven technologies developed for turmeric production system was ergonomically tested for ginger production system.

Package of the total seven technologies developed for turmeric production system consists.

\begin{tabular}{|c|c|c|}
\hline $\begin{array}{l}\text { Sr. } \\
\text { No. }\end{array}$ & $\begin{array}{l}\text { Name of the } \\
\text { technology }\end{array}$ & Use \\
\hline 1 & Digging tool & Digging soil \\
\hline 2 & Finger guards & $\begin{array}{l}\text { planting turmeric } \\
\text { rhizomes \& fertilizer } \\
\text { application }\end{array}$ \\
\hline 3 & Earthing up tool & Earthing up activity \\
\hline 4 & New khurpi & Weeding \\
\hline 5 & $\begin{array}{l}\text { Fertilizer } \\
\text { application bag }\end{array}$ & Fertilizer application \\
\hline 6 & Soybean mittens & Harvesting \\
\hline 7 & Wooden rake & $\begin{array}{l}\text { Turning ginger } \\
\text { fingers while drying }\end{array}$ \\
\hline
\end{tabular}

Ergonomic Evaluation of Selected Farm Activity

Total 46 healthy farm workers working in the field for 6-7 hrs/ day and 6days/ week and having minimum five years' experience of work in ginger production were selected for the study.

Location of the study: Pokharni, Katneshwar, Nandgaon, Bharati Camp Dist. Parbhani \& Hatta, Adgaon, Satephal villages of Dist. Hingoli were selected for the study.

No. of farm activities assessed \& subjects selected for the study: Planting (10), Weeding (09), Earthing up (10), Fertilizer application (10), Harvesting, Sorting \& cleaning (10) and drying (10) were the assessed activities and subjects.

\section{Mode of data collection}

For collection of data 46 female workers, three replications, 5 activities viz. planting, weeding, earthing up, fertilizer application, Harvesting, Sorting \& cleaning and two methods i. e. existing and improved were selected

Equipment used for the study: Polar heart rate monitor, Anthropometry kit, Sphygmomanometer, measuring tape and weighing balance

Measurement of Parameters: Following Measurement Parameters were used while making questionnaire for the study

Physiological load (1): Physiological cost of work $(\mathrm{PCW})=\mathrm{TCCW} /$ Total time of work

Rated perceived exertion (RPE) (4)

Very light-1, Light -2 , moderately light-3, Heavy -4 and Very heavy -5 
' $t$ ' test: ' $t$ ' test was used to find out the mean differences in variables. Following formula was used to assess ' $t$ ' value (3)

\section{Results and Discussion}

It was seen that majority of woman workers were in the age group of 30-40 years, belonging to nuclear family, within 2-4 family members, having monthly income Rs. 7,000$10,000 /$ - and were non literate. Body weight of majority of woman workers ranged between $35-55 \mathrm{~kg}$. and range of body height between $146-155 \mathrm{~cm}$.

\section{Physiological workload of women worker while performing selected activities in ginger production system}

Physiological workload of the selected women workers while performing selected activities in ginger production system was assessed by heart rate method. Selected parameters such as working heart rate, peak heart rate, energy expenditure, peak energy expenditure, cardiac cost of work (CCW), total cardiac cost of work (TCCW) and physiological cost of work (PCW) were compared in existing and improved method. In improved method work was performed by the women farm workers with the help of developed/ modified tools such as two digging tools, new khurpi and earthing up tool and mittens.

Assessment of physiological work load of women workers while performing activity planting rhizomes in ginger production system is shown in table 1. It is apparent from the table that physiological parameters such as working heart rate $\left(98 \mathrm{~b} . \mathrm{m}^{-1}\right)$, peak heart rate $\left(109\right.$ b. $\left.\mathrm{m}^{-1}\right)$, Energy expenditure (6.89 $\left.\mathrm{kjm}^{-1}\right)$, peak energy expenditure $\left(8.63 \mathrm{kjm}^{-1}\right)$, CCW (307 beats), TCCW (341 beats) and PCW (33 beats) were decreased in improved method. Whereas CCR (34 beats) is increased in improved method, but statistical analysis with ' $t$ ' test manifested non-significant results between existing and improved method.

Assessment of physiological work load of women workers while performing activity hand weeding in ginger production system is shown in table 2. It is clear from the table that peak heart rate $\left(110 \mathrm{~b} . \mathrm{m}^{-1}\right)$ was decreased in improved method. While working heart rate $\left(104 \mathrm{~b} . \mathrm{m}^{-1}\right)$, energy expenditure $\left(7.83 \mathrm{kjm}^{-1}\right)$, peak energy expenditure $\left(8.86 \mathrm{kjm}^{-1}\right), \mathrm{CCW}$ (339 beats), CCR (19 beats), TCCW (353.4 beats) and PCW (30.2 beats) were increased in improved method. Statistical analysis showed non-significant results between existing and improved method. The results are in lined with the results of Zend et al., 2020 for the technologies tested for turmeric production system (5).

Physiological work load of women workers while performing activity earthing up in ginger production system is depicted in table 3 . it is observed that all the parameters such as working heart rate $\left(113 \mathrm{~b} \cdot \mathrm{m}^{-1}\right)$, peak heart rate $\left(122 \mathrm{~b} . \mathrm{m}^{-1}\right)$, energy expenditure $\left(9.27 \mathrm{kjm}^{-}\right.$ ${ }^{1}$ ), peak energy expenditure $\left(10.65 \mathrm{kjm}^{-1}\right)$, CCW (789 beats), CCR (39 beats), TCCW (828 beats) and PCW (41.41 beats) were decreased in improved method, but statistically results between existing and improved method showed non-significant results.

Physiological work load of women workers while performing activity harvesting and cleaning in ginger production system is given in table 4. It is obvious from the table that all the physiological parameters such as working heart rate $\left(98\right.$ b. $\left.{ }^{-1}\right)$, peak heart rate $(105$ b. $\left.\mathrm{m}^{-1}\right)$, energy expenditure $\left(6.89 \mathrm{kjm}^{-1}\right)$, peak energy expenditure $\left(7.95 \mathrm{kjm}^{-1}\right), \mathrm{CCW}$ (493 beats), CCR (16 beats), $\operatorname{TCCW}(510$ beats) and PCW (24 beats) were decreased in improved method. Statistical analysis with ' $t$ ' 
test showed non- significant results between existing and improved method.

Hence, it can be concluded that there was no significant decrease/ increase in physiological work load when work was performed by existing method or improved method.

Table.1 Physiological workload of women farm workers while performing activity Planting rhizomes in ginger production system $(\mathrm{N}=10)$

\begin{tabular}{|c|c|c|c|c|}
\hline Particulars & $\begin{array}{c}\text { Existing } \\
\text { method } \\
(\text { Mean } \pm \text { SD) }\end{array}$ & $\begin{array}{c}\text { Improved } \\
\text { method } \\
(\text { Mean } \pm \text { SD) }\end{array}$ & $\begin{array}{c}\text { Decrease in } \\
\text { improved } \\
\text { over existing } \\
(\%)\end{array}$ & $\begin{array}{c}\text { 't' } \\
\text { values }\end{array}$ \\
\hline Working heart rate $\left(\mathrm{bm}^{-1}\right)$ & $100 \pm 11.4$ & $98 \pm 12.7$ & $2(2)$ & $1.32^{\mathrm{NS}}$ \\
\hline Peak heart rate $\left(\mathrm{bm}^{-1}\right)$ & $114 \pm 16.8$ & $109 \pm 14.5$ & $5(4.38)$ & $1.63^{\mathrm{NS}}$ \\
\hline Energy Expenditure $\left(\mathrm{kjm}^{-1}\right)$ & $7.19 \pm 1.8$ & $6.89 \pm 2.02$ & $0.3(8.76)$ & $0.73^{\mathrm{NS}}$ \\
\hline $\begin{array}{l}\text { Peak Energy Expenditure } \\
\left(\mathrm{kjm}^{-1}\right)\end{array}$ & $9.34 \pm 2.68$ & $8.63 \pm 2.30$ & $0.71(7.6)$ & $0.63^{\mathrm{NS}}$ \\
\hline CCW (Beats) & $364 \pm 110.2$ & $307 \pm 151$ & $57(15.6)$ & $0.96^{\mathrm{NS}}$ \\
\hline CCR (Beats) & $33 \pm 31.05$ & $34 \pm 24.7$ & $-1(38.2)$ & $0.07^{\mathrm{NS}}$ \\
\hline TCCW (Beats) & $398 \pm 129.1$ & $341 \pm 171.6$ & $57(14.32)$ & $0.83^{\mathrm{NS}}$ \\
\hline PCW (Beats) & $34 \pm 16.29$ & $33 \pm 18.22$ & $1(2.94)$ & $0.12^{\mathrm{NS}}$ \\
\hline
\end{tabular}

CCW - Cardiac cost of work, CCR - cardiac cost of recovery, TCCW-Total cardiac cost of work, PCW Physiological cost of work, NS - Non significant

Table.2 Physiological workload of woman farm workers while performing hand weeding in ginger production system $(\mathrm{N}=10)$

\begin{tabular}{|l|c|c|c|c|}
\hline Particulars & $\begin{array}{c}\text { Existing } \\
\text { method } \\
\text { (Mean } \pm \text { SD) }\end{array}$ & $\begin{array}{c}\text { Improved } \\
\text { method } \\
\text { (Mean } \pm \\
\text { SD) }\end{array}$ & $\begin{array}{c}\text { Increase/ } \\
\text { decrease in } \\
\text { improved over } \\
\text { existing (\%) }\end{array}$ & 't' \\
values \\
\hline Working heart rate $\left.\mathbf{( b m}^{-\mathbf{1}}\right)$ & $103 \pm 8.76$ & $104 \pm 7.22$ & $1(0.97)$ & $0.27^{\mathrm{NS}}$ \\
\hline Peak heart rate $\left(\mathbf{b m}^{-\mathbf{1}}\right)$ & $114 \pm 8.52$ & $110 \pm 8.99$ & $4(3.50)$ & $1.021^{\mathrm{NS}}$ \\
\hline Energy Expenditure $\left(\mathbf{k j m}^{-\mathbf{1}}\right)$ & $6.82 \pm 1.39$ & $7.83 \pm 1.14$ & $1(14.80)$ & $1.76^{\mathrm{NS}}$ \\
\hline Peak Energy Expenditure $\left.\mathbf{( k j m}^{-\mathbf{1}}\right)$ & $8.37 \pm 1.35$ & $8.86 \pm 1.43$ & $0.49(5.85)$ & $0.78^{\mathrm{NS}}$ \\
\hline CCW (Beats) & $334 \pm 131.2$ & $339 \pm 107.8$ & $5(1.49)$ & $0.093^{\mathrm{NS}}$ \\
\hline CCR (Beats) & $14 \pm 10.4$ & $19 \pm 16.3$ & $5(38.2)$ & $0.817^{\mathrm{NS}}$ \\
\hline TCCW (Beats) & $341 \pm 145.7$ & $353 \pm 115.8$ & $12(3.519)$ & $0.203^{\mathrm{NS}}$ \\
\hline PCW (Beats) & $23 \pm 9.71$ & $30 \pm 7.72$ & $7(29.0)$ & $1.78^{\mathrm{NS}}$ \\
\hline
\end{tabular}

CCW - Cardiac cost of work, CCR - cardiac cost of recovery, TCCW-Total cardiac cost of work,

PCW - Physiological cost of work, NS - Non significant 
Table.3 Physiological workload of woman farm workers while performing earthing up activity in ginger production system $(\mathrm{N}=10)$

\begin{tabular}{|l|c|c|c|c|}
\hline \multicolumn{1}{|c|}{ Particulars } & $\begin{array}{c}\text { Existing method } \\
(\text { Mean } \mathbf{\pm} \text { SD) }\end{array}$ & $\begin{array}{c}\text { Improved } \\
\text { method } \\
(\text { Mean } \pm \text { SD) }\end{array}$ & $\begin{array}{c}\text { Decrease in } \\
\text { improved over } \\
\text { existing (\%) }\end{array}$ & $\begin{array}{c}\text { 't' } \\
\text { Values }\end{array}$ \\
\hline Working heart rate $\left(\mathbf{b m}^{-\mathbf{1}}\right)$ & $119 \pm 13.6$ & $113 \pm 11.23$ & $6(5.04)$ & $1.07^{\mathrm{NS}}$ \\
\hline Peak heart rate $\left(\mathbf{b m}^{-\mathbf{1}}\right)$ & $127 \pm 12.63$ & $122 \pm 10.9$ & $5(3.93)$ & $0.94^{\mathrm{NS}}$ \\
\hline Energy Expenditure $\left(\mathbf{k j m}^{-\mathbf{1}}\right)$ & $10.16 \pm 2.16$ & $9.27 \pm 1.78$ & $0.89(8.75)$ & $1.01^{\mathrm{NS}}$ \\
\hline Peak Energy Expenditure $\left.\mathbf{( k j m}^{-\mathbf{1}}\right)$ & $11.49 \pm 2.0$ & $10.65 \pm 1.73$ & $0.84(7.31)$ & $1.01^{\mathrm{NS}}$ \\
\hline CCW (Beats) & $900 \pm 255.61$ & $789 \pm 204.52$ & $111(12.33)$ & $1.07^{\mathrm{NS}}$ \\
\hline CCR (Beats) & $48 \pm 28.56$ & $39 \pm 21.13$ & $9(18.75)$ & $0.8^{\mathrm{NS}}$ \\
\hline TCCW (Beats) & $948 \pm 269.8$ & $828 \pm 217.6$ & $120(12.65)$ & $1.09^{\mathrm{NS}}$ \\
\hline PCW (Beats) & $47 \pm 13.49$ & $41 \pm 10.88$ & $5.98(12.61)$ & $1.09^{\mathrm{NS}}$ \\
\hline
\end{tabular}

CCW - Cardiac cost of work, CCR - cardiac cost of recovery,

TCCW-Total cardiac cost of work, PCW - Physiological cost of work, NS - Non significant

Table.4 Physiological workload of woman farm workers while performing activity harvesting and cleaning in ginger production system $(\mathrm{N}=10)$

\begin{tabular}{|c|c|c|c|c|}
\hline Particulars & $\begin{array}{c}\text { Existing } \\
\text { method } \\
(\text { Mean } \pm \text { SD })\end{array}$ & $\begin{array}{c}\text { Improved } \\
\text { method } \\
(\text { Mean } \pm \text { SD) }\end{array}$ & $\begin{array}{c}\text { Decrease in } \\
\text { improved over } \\
\text { existing (\%) }\end{array}$ & $\begin{array}{c}\text { 't' } \\
\text { Values }\end{array}$ \\
\hline Working heart rate $\left(\mathrm{bm}^{-1}\right)$ & $101+6.82$ & $98+7.41$ & $3(2.97)$ & $0.94^{\mathrm{NS}}$ \\
\hline Peak heart rate $\left(\mathrm{bm}^{-1}\right)$ & $111 \pm 7.22$ & $105 \pm 7.49$ & $6(5.40)$ & $1.82^{\mathrm{NS}}$ \\
\hline Energy Expenditure $\left(\mathrm{kjm}^{-1}\right)$ & $7.37 \pm 1.08$ & $6.89 \pm 1.17$ & $0.48(6.51)$ & $0.95^{\mathrm{NS}}$ \\
\hline Peak Energy Expenditure $\left(\mathrm{kjm}^{-1}\right)$ & $8.96 \pm 1.14$ & $7.95 \pm 1.19$ & $1.01(11.27)$ & $1.94^{\mathrm{NS}}$ \\
\hline CCW (Beats) & $568 \pm 109.9$ & $494 \pm 74.06$ & $74(13.02)$ & $1.76^{\mathrm{NS}}$ \\
\hline CCR (Beats) & $27 \pm 15.29$ & $17 \pm 12.37$ & $10(37.03)$ & $1.65^{\mathrm{NS}}$ \\
\hline TCCW (Beats) & $595 \pm 120.02$ & $510 \pm 85.12$ & $85(14.28)$ & $1.82^{\mathrm{NS}}$ \\
\hline PCW (Beats) & $28 \pm 6.12$ & $25 \pm 6.46$ & $3(10.71)$ & $1.06^{\mathrm{NS}}$ \\
\hline
\end{tabular}

CCW - Cardiac cost of work, CCR - cardiac cost of recovery, TCCW-Total cardiac cost of work, PCW - Physiological cost of work, NS - Non significant

Table.5 Rating of perceived exertion (RPE) of farm women while performing selected activities in ginger production system

\begin{tabular}{|l|c|c|c|c|c|c|}
\hline \multicolumn{1}{|c|}{ Name of the activity } & $\begin{array}{c}\text { Existing } \\
\text { method } \\
\text { (Mean } \pm \\
\text { SD) }\end{array}$ & $\begin{array}{c}\text { Work load } \\
\text { category as } \\
\text { per RPE }\end{array}$ & $\begin{array}{c}\text { Improved } \\
\text { method } \\
\text { (Mean } \pm \\
\text { SD) }\end{array}$ & $\begin{array}{c}\text { Work load } \\
\text { category as } \\
\text { per RPE }\end{array}$ & $\begin{array}{c}\text { Decrease in } \\
\text { improved over } \\
\text { existing }(\boldsymbol{\%})\end{array}$ & $\begin{array}{c}\text { 't' } \\
\text { values }\end{array}$ \\
\hline Planting ginger rhizomes $(\mathbf{n = 1 0})$ & $4.7 \pm 1.36$ & $\mathrm{VH}$ & $3.2 \pm 1.01$ & $\mathrm{M}$ & $1.5(31.91)$ & $2.8^{*}$ \\
\hline Hand weeding(n=10) & $3.53 \pm 0.63$ & $\mathrm{H}$ & $3.07 \pm 0.65$ & $\mathrm{M}$ & $0.46(13.03)$ & $\mathrm{NS}$ \\
\hline Earthing up $(\mathbf{n = 1 0})$ & $4.6 \pm 1.2$ & $\mathrm{VH}$ & $3.09 \pm 0.98$ & $\mathrm{M}$ & $1.51(32.82)$ & $3.14 *$ \\
\hline Manual fertilizer application (n=06) & $4.7 \pm 1.02$ & $\mathrm{VH}$ & $4.0 \pm 0.99$ & $\mathrm{H}$ & $0.7(14.89)$ & $\mathrm{NS}$ \\
\hline Harvesting \& cleaning $(\mathbf{n}=\mathbf{1 0})$ & $3.8 \pm 0.67$ & $\mathrm{H}$ & $2.7 \pm 0.59$ & $\mathrm{M}$ & $1.1(28.94)$ & $3.9 * *$ \\
\hline
\end{tabular}

*- Significant at 5\%, NS - Non significant, Figures in parenthesis indicates percentages 
Table.6 Time and work study of the selected activities in ginger production system

\begin{tabular}{|c|c|c|c|c|}
\hline $\begin{array}{l}\text { Name of the } \\
\text { activity }\end{array}$ & $\begin{array}{c}\text { Existing } \\
\text { method } \\
(\text { area: } \mathbf{m} / \mathrm{hr}) \\
(\text { Mean } \pm \text { SD) }\end{array}$ & $\begin{array}{c}\text { Improved } \\
\text { method } \\
\text { (area: } \mathbf{m} / \mathbf{h r}) \\
(\text { Mean } \pm \text { SD) }\end{array}$ & $\begin{array}{c}\text { Increase/ } \\
\text { decrease } \\
\text { improved over } \\
\text { existing }(\%)\end{array}$ & $\begin{array}{c}\text { 't' } \\
\text { values }\end{array}$ \\
\hline Planting of ginger rhizomes & $107.52 \pm 30.17$ & $142.32 \pm 36.3^{(\mathbf{a})}$ & $34.8(32.36)$ & $2.33 *$ \\
\hline Planting of ginger rhizomes & $101.26 \pm 27.32$ & $117.11 \pm 29.37^{(\mathbf{b})}$ & $15.85(15.65)$ & NS \\
\hline Hand weeding & $10.51 \pm 3.2$ & $9.6 \pm 2.9$ & $0.91(8.65)$ & NS \\
\hline Earthing up & $68.91 \pm 5.95$ & $91.72 \pm 8.64$ & $14.87(21.57)$ & $6.87 * *$ \\
\hline Manual fertilizer application & $329.53 \pm 219.68$ & $367.01 \pm 258.83$ & $37.48(11.37)$ & NS \\
\hline $\begin{array}{l}\text { Harvesting and cleaning of } \\
\text { ginger rhizomes }\end{array}$ & $\begin{array}{c}16.77 \pm 3.07 \\
(\mathrm{~kg} / \mathrm{hr})\end{array}$ & $\begin{array}{c}24.99 \pm 5.89 \\
(\mathrm{~kg} / \mathrm{hr})\end{array}$ & $7.89(47.04)$ & $3.75 * *$ \\
\hline
\end{tabular}

By using digging tool Ukari, (b)- By using finger guards

$*$ - significant at $5 \%$, ** - significant at $1 \%$, NS - Non significant, Figures in parenthesis indicates percentages

Rating of perceived exertion (RPE) of farm women while performing selected activities in ginger production system

Rating of perceived exertion (RPE) of farm women while performing selected activities in ginger production system is shown in table 5 . It is indicated from the table that there was significant decrease $(29-33 \%)$ in perceived exertion in improved method of planting $\left(2.8^{*}\right)$, earthing up activity $\left(3.14^{*}\right)$ and harvesting and cleaning activity (3.9**), whereas in weeding and fertilizer application activity there was no significant difference found in RPE (13-15\%).

All the selected activities in ginger production system were perceived as very heavy to heavy activities by the entire selected women farm worker.

In improved method, all respondents felt that the work load is reduced and activities are moderately heavy.

In conclusion, it can be said that perceived exertion of selected activities performed by woman farm workers was reduced in improved method, but significant in planting, earthing up and harvesting and cleaning activities.
Time and work study of the selected activities in ginger production system

Time and work study of the selected activities in ginger production system is reported in table 6. It is revealed that work completed for the activities planting of ginger rhizomes by using digging tool Ukari (142.32 m/hr), planting of ginger rhizomes by using finger guards $(117.11 \mathrm{~m} / \mathrm{hr})$, earthing up (91.72 $\mathrm{m} / \mathrm{hr}$ ), manual fertilizer application (367.01 $\mathrm{m} / \mathrm{hr}$ ) and harvesting and cleaning of ginger rhizomes $(24.99 \mathrm{~kg} / \mathrm{hr})$ in improved method was more. While in the activity hand weeding work completed was more in existing method $(10.51 \mathrm{~m} / \mathrm{hr})$. Statistical analysis showed significant results for the activities planting of ginger rhizomes by using digging tool Ukari $\left(2.33^{*}\right)$, earthing up activities $(6.87 * *)$ and harvesting and cleaning of ginger rhizomes $\left(3.75^{* *}\right)$.

It can be concluded that developed technologies viz. digging tool (Ukari) for planting, earthing up tool (Sawadi) for earthing up activity and mittens for harvesting and cleaning used by women farm worker in ginger production system were successful for increasing pace of work. 
In conclusion the cardiac cost of work for planting and earthing up activities performed by women farm worker in improved method over existing method was reduced by 16 and 12 percent respectively in Ginger production system. Rated perceived exertion was decreased by 13-32 per cent in improved method of planting, weeding, earthing up and manual fertilizer application and harvesting and cleaning activities. The developed technologies viz. digging tools (Ukari and finger guards), new khurpi, Sulbha bag and Earthing up tool (Sawadi) used by farm women in ginger production system for planting, weeding, earthing up and manual fertilizer application activities were successful in increasing pace of work.

\section{References}

1. Mrunalini, A; Esther, S. and Deepika, J. (2015). Characterization of drudgery in vegetable production system. Int J. Sci. Res. Vol. 4(4):256-258. ISSN: 2277-8179 .

2. Salunke, P. Y. and Raskar, M. B. (2017).Variety wise CBR of ginger cultivation: A comparative study of Satara and Aurangabad District, Research Front; vol.1:58-61.

3. Sharma, H. L. (2005). Basic statistical methods with application. Agrotec publishing academy, Udaipur pp: 78, 261, 306, 331.

4. Varghese, M. A.; Saha, P. N. and Atreya N. A. (1994). rapid appraisal of occupational workload from a modified scale perceived exertion. Ergonomic; vol. 37: 485- 495.

5. Zend, J. P; Revanwar,. M. S. and Admankar S. N. (2015). Characterization of drudgery of farm women in soybean production system, Ergonomics in caring people, proceedings of HWWE. Springer Publication.; 125 - 130. ISBN: 978-98110-4980-4(e book).

\section{How to cite this article:}

Jayshree Rodge, Manjusha Rewanwar and Swati Gaikwad. 2020. Assessment of Low Cost Technologies for Drudgery Mitigation in Ginger Production System. Int.J.Curr.Microbiol.App.Sci. 9(08): 3866-3872. doi: https://doi.org/10.20546/ijcmas.2020.908.445 